\title{
The Con/Lib Agenda for Home Affairs
}

\section{John Benyon}

The principal functions of a government are to maintain national security and to regulate conflict and secure order in society. Consequently, what is often referred to as 'law and order' or 'home affairs' is a key policy arena for any government.

It was clear from the outset of the Coalition that one of the central issues that united the Conservatives and the Liberal Democrats was common opposition to what they perceived to be the Labour government's illiberal policies which had changed the relationship between individual citizens and the state. This was described in the Foreword to the Coalition programme as 'the relentless incursion of the state into the lives of individuals' (HM Government 2010 p. 8). Section 3 of the Coalition programme asserted that the new government believed that 'the British state has become too authoritarian and over the past decade it has abused and eroded fundamental human freedoms and historic civil liberties. We need to restore the rights of individuals in the face of encroaching state power' (HM Government 2010 p. 11).

These are strong statements about civil liberties in Britain and the extent to which they were undermined by New Labour and subsequent government statements and policies have reinforced them. For example, on 13 July 2010, announcing that a rapid review of counterterrorism powers, the Home Secretary Theresa May said:

'National security is the first duty of government but we are also committed to reversing the substantial erosion of civil liberties. I want a counter-terrorism regime that is proportionate, focused and transparent. We must ensure that in protecting public safety, the powers which we need to deal with terrorism are in keeping with Britain's traditions of freedom and fairness' (Ministry of Justice 2010? P. ?).

This view of the shifting balance of power between citizens and the state in terms of law and order dovetailed with the Coalition government's narrative that under New Labour there had been too much 'big government', too much centralisation and too much 'top-down control'. 
The Coalition programme declared that it was time to disperse power and to hand it back to people and communities. This theme of a smaller state and greater local involvement and influence is evident in the Coalition's policies and approach to home affairs.

In the United Kingdom 'home affairs' includes a wide assortment of policies and activities, some of which are retained by the national government, while others are devolved to the administrations in Scotland, Wales and Northern Ireland and yet others are the responsibility of local authorities. They range from the regulation of burials and cremation through electoral administration and 'modernisation' to the use of surveillance by local authorities and the regulation of the use of animals for research. However, the principal policy areas of home affairs are crime and criminal justice, punishment and imprisonment, policing, security and public order, immigration, and civil liberties and equalities.

The Home Office is the lead department for matters such as immigration and passports, drugs policy, counter-terrorism, crime and its prevention, and the police. Until a few years ago it was also responsible for punishment and prisons, the probation service and youth justice. This changed when the Ministry of Justice was set up on 9 May 2007. This is a large department with some 95,000 staff and as well as punishment its work includes criminal, civil and family justice and responsibility for the courts and a range of tribunals. Its activities also include supporting victims of crime, reducing reoffending and safeguarding human rights. Another department involved in home affairs is the Attorney General's Office which oversees the work of the Crown Prosecution Service and the Serious Fraud Office.

The Prime Minister and the Deputy Prime Minister play important roles in the home affairs arena, for example in policies and debates on national security and counter-terrorism and also on the civil liberties agenda. The Home Secretary in the new Coalition, Conservative Theresa May, is also Minister for Women and Equalities. Minister of state Nick Herbert, who is a joint appointment with the Justice Department, has responsibility for crime and policing, including anti-social behaviour. Fellow Conservative Damian Green is minister of state leading on immigration and asylum and border controls. The third minister of state, Baroness Neville-Jones, has responsibility for security and counter-terrorism, security for the Olympic Games and extradition and mutual legal assistance. Parliamentary under-secretary of state James Brokenshire has responsibility for crime prevention and also drugs and alcohol, public 
order, CCTV and DNA. The only Liberal Democrat is junior minister Lynne Featherstone MP who has responsibility for equality issues and for freedom of information.

The Secretary of State for Justice and Lord Chancellor is the Conservative political heavyweight Kenneth Clarke. There are two ministers of state - Lord McNally, the only Liberal Democrat in the department, and Nick Herbert, the joint appointment with the Home Office. Crispin Blunt MP is the parliamentary under-secretary of state with responsibility for prisons and probation, youth justice, and sentencing, and his fellow Conservative junior minister Jonathan Djanogly leads on legal aid, the courts, parole and tribunals. The Attorney General in the government is Dominic Grieve and the Solicitor General is fellow Conservative MP Edward Garnier. All but two of the 12 politicians appointed to the Home Office, Ministry of Justice and Attorney General's Office were Conservatives, with Conservatives in the top positions.

\section{The Coalition Reform Agenda}

In the home affairs arena the new government swept into action with much activity and many policy announcements. In keeping with their declarations on civil liberties and the reversal of New Labour's 'authoritarian' policies, the first piece of legislation was the Identity Documents Bill to scrap identity cards and the National Identity Register. The bill was introduced to the Commons on 26 May and received the Royal Assent on 21 December 2010.

\section{Crime and criminal justice}

During the Labour Party's period in office crime fell significantly. Overall crime fell by 43 per cent between 1997 and 2010 while violent crime was down by over 40 per cent. Figures published in July 2010 showed that the fall in crime had persisted despite the recession. The figures were confirmed by the 2010 British Crime Survey but, perversely, that also showed that although a majority of people believed crime had fallen in their own neighbourhood 66 per cent continued to believe that crime was rising nationally.

The Coalition programme included a raft of commitments on home affairs, a number of them in keeping with its commitment to 'localism'. These included publication of monthly local crime statistics, regular beat meetings with the police, and ensuring hospitals shared 
information about gun and knife crime with local police (HM Government 2010b p. 13). In addition, the Coalition promised to take action on the abuse of alcohol which is linked to nearly half of all violent crimes. This included banning the sale of alcohol below cost price, reviewing alcohol taxation to tackle binge drinkers, and revising the licensing laws to give stronger local powers to revoke licences. Stating 'we take white-collar crime as seriously as other crime' the Coalition (HM Government 2010b p. 9) undertook to create a single agency to tackle serious organised crime, absorbing the work of the Serious Fraud Office and other bodies.

On criminal justice, the Coalition promised a fundamental review of legal aid and a green paper was published on 15 November 2010. The proposals were intended to 'reform and rebalance the justice system' and to make it quicker and cheaper. The Justice Secretary, Kenneth Clarke, said that the current legal aid system was one of the most expensive in the world and must be reformed. Another paper on civil litigation proposed to tackle the rising costs incurred by people who are sued in 'no win no fee' cases. The Coalition also pledged to give individuals more legal protection to prevent crime and apprehend criminals and powers to defend themselves against intruders (HM Government 2010b p. 13). In addition, the programme said that criminal records bureau checks would be scaled back to sensible levels (HM Government 2010 b p. 20).

\section{Punishment and imprisonment}

When Labour came into office in 1997 the prison population in England and Wales was 61,114 and when it left in May 2010 it had increased to 85,009 - a rise of 39 per cent. Even more striking was the rise since 1993, when Kenneth Clarke was Home Secretary. Then the prison population was an average figure of 44,566 but by November 2010 it had risen by 92 per cent to 85,454 (HM Prison Service, 2010). Mr Clarke, in charge of prisons once more, confessed he was amazed at this increase. He said that if such a prediction had been made in 1993 he would have dismissed it as 'ridiculous'.

One factor raised in the debate about the incarceration rate was the volume of legislation on crime under New Labour and the consequent huge rise in the number of criminal offences on the statute book. In 2003 alone there were six criminal justice statutes, most notably the Criminal Justice Act which led to longer prison sentences. It was reported that 3,600 new 
criminal offences were created during Labour's time in office. In July 2009 Lord Judge, the Lord Chief Justice, pleaded 'can we possibly have less legislation, particularly in the field of criminal justice'. The Coalition pledged to stop 'the proliferation of new criminal offences' (HM Government 2010b p. 11).

The Coalition announced a 'rehabilitation revolution' involving a comprehensive sentencing policy review aimed at deterring crime, protecting the public, punishing offenders and cutting reoffending (HM Government 2010b p. 23). Initiatives were promised to find new secure treatment for mentally ill and drug offenders, and to pay independent providers to reduce reoffending. Deductions from prisoners' earnings would be paid into the victims' fund, up to 15 new rape crisis centres would be established, and anonymity would be introduced for defendants in rape cases.

A green paper on sentencing, entitled Breaking the Cycle: Effective Punishment, Rehabilitation and Sentencing of Offenders, was published on 7 December 2010. The focus of the proposals was to 'punish criminals more effectively and reduce reoffending' (Ministry of Justice $2010 \mathrm{e}$ p. ?). The proposals included more emphasis on work in prison, more demanding community punishment, tougher curfew requirements, greater use of restorative justice and increased reparations to victims, improved youth justice, and introducing payment-by-results for independent providers.

In addition, and importantly, the green paper promised to reform the use of indeterminate sentences of imprisonment for public protection (IPP). This form of sentencing was introduced in the Criminal Justice Act 2003 and came into effect in 2005. It was modified in 2008. The object is to keep the offenders in prison until they can show they are not a threat to the public. Each IPP prisoner receives a minimum tariff but the great majority remain in prison long after they have served it. One reason is that IPP prisoners are obliged to complete certain offender behaviour courses before being considered for release by the Parole Board but many prisons have not had the resources to offer such courses. The IPP was described by Anne Owers, chief inspector of prisons, as 'a worked example of how not to legislate' (Needs reference and page no).

In 2010 there were 6,130 people serving IPP sentences with 2,850 being held well beyond their tariff point. Only 94 IPP prisoners had ever been let out of prison. The Coalition reforms 
proposed that IPP sentences should be reserved for the most serious offenders and the onus of the release test should on the authorities to prove why the prisoner posed a serious risk of harm to the public. The Justice Department estimated that reducing remand time in prison would save 1,300 places a year, while offering foreign offenders the chance to pay a fine and leave the country would save another 500 places annually. Offering defendants a reduction of up to half their sentence if they pleaded guilty was expected to save 3,400 prison places by 2014-15.

The Coalition also promised to bring in 'effective measures' to reduce anti-social behaviour and low-level crime, including restorative justice. The Home Secretary subsequently announced the abolition of asbos - anti-social behaviour orders - seen by some as a hallmark of Tony Blair's approach to crime. At their peak, in 2005, 4,122 new asbos were issued. They were not just used against young offenders but included a wide variety of people such as an 87-year-old man who was abusive to his neighbours and a woman who was banned from making excessive noise while having sexual relations anywhere in England. Problems with asbos were that some young people saw them as a mark of distinction and they were difficult to enforce, with up to 61 per cent not being observed.

\section{Policing, security and public order}

The Coalition promised reform of policing with greater freedom from ministerial control and more accountability to local people. 'Time-wasting bureaucracy' would be reduced, better technology would be used and health and safety laws would be changed to enable 'common sense policing' (HM Government 2010b, p. 13). A key and controversial proposal was to bring in a directly-elected individual to oversee each police force. The policing minister, Nick Herbert, called for 'new thinking' with the police holding regular beat meetings with local residents. Police forces would be relieved of central targets and top-down controls.

The Coalition government stated that its 'primary responsibility is to ensure national security' and it had already set up a National Security Council (HM Government 2010b p. 24). It would undertake a security review and publish a National Security Strategy, and review all counter-terrorism legislation including control orders. Groups that incited violence and hatred would be proscribed, and the use of intercept evidence in the courts would be pursued. On 18 October 2010 the government's national security strategy white paper was published (HM 
Government 2010). One of its themes was that Britain faced 'an age of uncertainty' with often unforeseen threats (HM Government 2010a p. ?).

The review identified four 'tier one' threats to the country - international terrorism, including the use of chemical, biological, radiological or nuclear $(\mathrm{CBRN})$ materials, cyber attacks, international military crises, and major accidents or natural hazards. 'Tier two' threats included an attack by another state involving CBRN weapons, overseas instability or insurgency, a big rise in the level of organised crime, and disruption to the transmission of information by satellites. 'Tier three' risks included a conventional military attack, a significant rise in terrorism, organised crime, illegal immigrants, disruption to oil or gas supplies, an accident at a UK civil nuclear site, and disruptions to international supplies of resources.

Among the measures under review was the use of stop and search about which there were accusations of misuse. In June 2010 it was announced that thousands of people had been unlawfully stopped and searched under the Terrorism Act 2000 and 14 different police forces were reported to have illegally used the powers since 2001. The Home Office released figures showing that 101,248 people had been stopped and searched under counter-terrorism legislation in 2009 with not a single arrest for a terrorist offence. Following a ruling in the European Court of Human Rights, the Home Secretary decided to scrap the police use of section 44 random stop and search powers although Alan Johnson, the shadow Home Secretary, said this would restrict policing.

There was also criticism of the activities of the National Public Order Intelligence Unit (NPOIU) run by the Association of Chief Police officers (ACPO). It came to the fore in January 2011 when the activities of an undercover police officer led to the collapse of the prosecution of six environmental activists in Nottinghamshire. It became clear that he was only one of several undercover police officers operating within the green movement at an estimated annual cost of $£ 200,000$ each. Considerable concern was expressed about whether the undercover officers were acting as agents provocateur and about the accountability and propriety of ACPO itself. The policing minister announced significant changes in early 2011.

The Coalition's planned police reforms were outlined in Policing in the $21^{\text {st }}$ Century: Reconnecting Police and the People, published on 26 July 2010 (Home Office 2010b). It was 
described by the Home Secretary as the 'most radical reform of policing for 50 years' (Home Office $2010 \mathrm{~b}$ p. ?). It proposed to replace police authorities in England and Wales with elected police and crime commissioners. 'Community crime fighters' would be created local people who would take part in patrols with police officers (Home Office 2010b p. ?). The green paper also proposed the end of the National Policing Improvement Agency and the Serious Organised Crime Agency (SOCA) and the creation of a more wide-ranging National Crime Agency.

The resultant Police Reform and Social Responsibility Bill was introduced to the House of Commons on 30 November 2010. In addition to the elected commissioners, the Bill would change the regulation of protest around Parliament Square and also the process for issuing private arrest warrants. It included the promised overhaul of the licensing regime to give more power to local authorities and the police to tackle problematic premises. The minister for crime prevention said 'It's now time that local communities are put in charge and allowed to reclaim our high streets for sensible law-abiding drinkers' (HC Deb ?).

\section{Immigration}

The Coalition programme declared that immigration must be controlled and capped to ensure cohesion and protect public services (HM Government 2010b p. 21). Among the promised initiatives were an end to the detention of children, an annual limit on non-EU economic migrants, the reintroduction of exit checks, action to reduce abuse by students, and improvements to the asylum system. A key proposal was to set up a dedicated border police force to improve national security and immigration controls, and to prevent trafficking of people, drugs and weapons.

Two cases highlighted the human issues surrounding asylum seekers. On 2 August 2010 Osman Rasul, described as 'a destitute asylum-seeker', jumped to his death in Nottingham. The 27-year-old Iraqi Kurd had lost legal aid for his nine-year quest to stay in the UK and had been turned away from the Home Office immigration office in Croydon. In October 2010 an Angolan man, Jimmy Mubenga, died after he became unwell while private security guards attempted to deport him forcibly on a BA flight to Luanda. He had spent 16 years in the UK trying to be allowed to stay. He left a wife and five children. 
On 23 November the Home Secretary announced measures to control immigration from outside Europe. The aim was to reduce annual non-EU immigration from 196,000 in 2009 to 'tens of thousands' by 2015. The new rules set an annual limit of 21,700 for tier-one and tiertwo migrants. Changes to the points-based system would restrict workers transferred by companies to those earning $£ 40,000$ a year, and would limit immigration of skilled workers. A further consultation was announced on students - the largest category of migrants. It was proposed that student visas would largely be limited to degree level with a more onerous regime for students at public and private colleges. It was estimated that this would result in a cut of around 40 per cent to the 300,000 students visas issued each year.

\section{Civil liberties and equalities}

The new government affirmed 'we will be strong in defence of freedom' (HM Government $2010 \mathrm{~b}$ p. 11). That would entail 'a full programme of measures to reverse the substantial erosion of civil liberties and roll back state intrusion' (HM Government 2010b p. ?). The Coalition programme promised to bring in a freedom bill, scrap identity cards, halt the next generation of biometric passports, and extend the scope of the Freedom of Information (FOI) Act.

The Coalition also promised to protect trial by jury, restore rights to non-violent protest, introduce safeguards against the misuse of anti-terrorism laws, further regulate CCTV and stop storage of internet and email records. A commission would look into a British bill of rights that would protect British liberties although in fact this was designed to defuse a potential row between some Conservatives and Liberal Democrats over whether to retain the Human Rights Act. The programme also promised greater protection for people against aggressive bailiffs, making repossession a last resort (HM Government 2010b p. 12).

In the section on equalities the Coalition programme said action was needed to 'tear down' barriers to social mobility and equal opportunities (HM Government 2010b p.18). Policies included promoting equal pay and ending discrimination at work, and improving community relations and opportunities for black, Asian and minority ethnic people.

Another key concern was the effect of counter-terrorism measures. An important issue was control orders on suspected terrorists who have not been charged with any offence. These 
were introduced by New Labour in 2005 after the internment of suspects in Belmarsh prison was declared unlawful. Control orders impose significant restrictions on the individual, including tagging, curfews, and bans on movement. In January 2011 it was reported that a compromise on control orders had been agreed between the Prime Minister, Deputy Prime Minister and Home Secretary. This would mean an end to house arrest and greater use of surveillance and tagging of suspects. It was also agreed to reduce the maximum period a person can be held without charge from 28 days to 14 days.

A review of counter-terrorism was set up in July 2010 with the aim of reporting in the autumn. In the event the report was delayed until 2011 and had not been published at the time of writing. The purpose of the review was to look at the balance between security and civil liberties and where possible 'to provide a correction in favour of liberty'. The review was asked to examine six anti-terrorism measures including control orders, section 44 stop and search powers, the use of the Regulation of Investigatory Powers Act 2000 (RIPA) by local authorities and access to communications data, the use of 'deportation with assurances', measures to deal with organisations that promote hatred, and the detention of suspects without charge.

\section{Implications of the Comprehensive Spending Review (CSR)}

The budgets for both the Home Office and the Ministry of Justice were cut as expected in the October 2010 CSR, with both departments subject to a reduction of 23 per cent in the period up to 2014-15. The Law Officers' departments were subject to a 24 per cent cut.

The CSR reported that Home Office savings would be achieved through reducing overheads, expenditure on consultants, the size of the workforce and 'reprioritising resources to the front line' (HM Treasury 2010 page no. preferable 2.60). Funds were provided to support the Coalition's policing changes, including elected police and crime commissioners, but overall there would be a reduction of 14 per cent in police resources - and that assumed that police authorities increased the police precept each year. Savings were expected to result from improved efficiencies and less back-office paperwork. Capital investment was earmarked to protect the UK's border and to tackle crime and terrorism. Central targets would be ended and wasteful bureaucracy and form-filling would be cut. Furthermore, the government would ‘modernise pay and conditions' (HM Treasury 2010 p. ?). Money had been earmarked to set 
up a new National Crime Agency to fight organised crime, protect the UK's borders and provide other national services. The UK Border Agency would be expected to save $£ 500$ million. Migration fees would rise to include a contribution towards managing the UK border.

The Ministry of Justice's budget would fall from $£ 8.9$ million to $£ 7.3$ million in $2014-15$. This would necessitate delivering better value for money, reforms to legal aid, and changes to sentencing to stop the 'unsustainable' rise in the prison population and to cut reoffending. The proposals for reforming the legal aid system were published in a consultative paper in November 2010 and the Justice Secretary said that the annual expenditure of over $£ 2$ billion could not continue. If fully implemented the changes would result in estimated savings of $£ 350$ million a year.

The CSR admitted the cuts in legal aid 'will involve taking tough choices' (HM Treasury 2010 p. ?). The implications were that some vulnerable groups, such as asylum seekers including victims of torture and violence, would be adversely affected. The Legal Services Commission (LSC) plays a central role and its recent track record had been subject to considerable criticism even before the cuts. For example, in June 2010 the Refugee and Migrant Justice group folded because of delayed payments from the LSC, amounting to nearly $£ 2$ million, some of which had reportedly been owed for two years. As a result of the closure, up to 10,000 asylum seekers were left without legal representation.

Reform of sentencing policy is fundamental to the government's plans. The remorseless rise in the prison population under New Labour would be halted and a number of new prisons which Labour had planned were stopped. In December 2010 the decision to cancel a new 600-place prison in Merseyside was announced and on 13 January 2011 the Ministry of Justice said that two prisons - Lancaster Castle and Ashwell - would be closed with the loss of 849 places. It was reported that it cost around $£ 45,000$ a year to keep each prisoner in jail. Even more strikingly, it was reported in 2010 that over 2,000 children aged 10 to 17 were held in prison and each one cost some $£ 100,000$ a year - over three times the cost of sending a child to Eton.

The Coalition's plans included tougher community penalties, restorative justice, and paying private and voluntary providers to deliver reductions in reoffending. A significant proposal 
was to set up mental health liaison services to try to divert mentally ill offenders away from the justice system into treatment. Alongside the sentencing reforms, the Coalition planned to reform the wider criminal justice system. Many of the reforms were designed to save money, such as the plan to close under-used courts and to try to find alternatives such as mediation. In December 2010 it was announced that 142 magistrates and county courts would be closed to save $£ 37$ million. The budget cuts will also necessitate fewer staff at the Justice Ministry’s headquarters and a reduction in capital spending of 50 per cent, including prison building.

The budget cuts for the Law Officers' departments will affect funding for bodies such as the Crown Prosecution Service (CPS) and the Serious Fraud Office. The CSR stated that the CPS will 'radically reduce its cost base while maintaining and strengthening its capability' (HM Treasury 2010 pg no preferable para 2.76). Quite how this will be achieved remains to be seen.

\section{Radical Reform or Continuity?}

The Coalition's plans for home affairs represented a radical break with the approach of the previous Labour government. The Home Office Draft Structural Reform Plan set out the Coalition's plans 'to turn government on its head' by putting power in the hands of people and communities (Home Office 2010a p. ?):. It highlighted the government's five departmental priorities:

1. Enable police and local communities to tackle crime and anti-social behaviour;

2. Increase the accountability of the police to citizens;

3. Secure the UK borders and control immigration;

4. Protect people's freedoms and civil liberties;

5. Protect people from terrorism. (Home Office 2010a p. 2)

In each of these policy fields the Coalition's agenda included marked departures from what had gone before. The Coalition's decision to curtail late-night drinking reversed Labour's attempt to stop binge-drinking and to create a 'cafe culture' by relaxing licensing hours. The changes to policing included in the Police Reform and Social Responsibility Bill, such as the introduction of local police and crime commissioners and the reduction of national targets, 
were also a radical change from Labour's policies. This was the case with tighter immigration controls and the introduction of the new border police force.

The break between the Labour government and the new administration was illustrated by their different policies on civil liberties and particularly identity cards. The Labour Manifesto stated: 'we are proud of our record on civil liberties' (Labour Party 2010 p. 5:5?). By contrast, the Coalition parties were highly critical of the 'authoritarianism' under New Labour and the 'abuse and erosion' of civil liberties. The programme of the new government included a commitment to 'roll back state intrusion' but for some this was a huge task. In The Guardian on 26 May 2010, Simon Jenkins wrote: 'The Queen's speech and pre-announced cuts will cleanse only the most fouled of Labour's stables. Illiberal registers, databases, inspectorates and regulatory quangos typified the regimes of Tony Blair and Gordon Brown and obsessed such control-freak ministers as David Miliband and Ed Balls' (Jenkins 2010).

Theresa May said that the end of identity cards was the 'first step of many' to 'reduce control of the state over decent, law-abiding people' (May 2010? and include in Bib) and Nick Clegg said it was a 'major step in dismantling the surveillance state' (Clegg 2010? and include in Bib). However, concern was voiced by opponents of 'the database state' when the Deputy Prime Minister said that from 2014 a new form of electoral register would mean that people would have to provide more information about themselves including signature, national insurance number and date of birth. Some saw this as the introduction of a national identity register by another means and argued that this information would then be sold to private companies.

There were also clear differences between the Coalition and the Labour Party on civil liberties and counter-terrorism. In January 2011 Ed Balls, then shadow Home Secretary, alleged that the Coalition was putting their parties' interests before those of the country. On the issue of control orders, Balls said: 'It increasingly looks as though politics and holding the Coalition together and appeasing backbenchers is becoming more important in the minds of Nick Clegg and the Prime Minister than doing the right thing' (Balls 2011? and include in Bib)).

The Ministry of Justice Draft Structural Reform Plan, published in July 2010, listed five departmental priorities some of which echoed those of the Home Office: 
1. Reform of sentencing and penalties;

2. Rehabilitation revolution;

3. Courts and legal aid;

4. Reform of the prison estate;

5. Civil liberties (Ministry of Justice 2010a p. 2).

On the first, second and fourth priorities there was a huge contrast between the Coalition's policies and those of the last Labour government. The Commission on English Prisons Today (2009) pointed out that the prison population rates place England and Wales amongst the very highest in Europe with 155 people per 100,000 in prison compared with 96 in France, 88 in Germany and 71 in Denmark. The rise in the prison population over 50 years has been dramatic from 26,198 in 1960 , which was a rate of some 52 per 100,000 people, to 42,264 in 1980 (83 per 100,000), to 61,114 in 1997 (120 per 100,000) when New Labour came into power, to the level at the end of 2010 of 85,454 (155 per 100,000 people). The outgoing Chief Inspector of Prisons, Anne Owers, reported that the increases in the number of people incarcerated had brought all sorts of pressures and made the system 'brittle'. She welcomed Ken Clarke's wish to reduce the size of the prison population and the promise of a new look at sentencing (Owers 2010 ? and include Bib).

The former chief inspector of prisons, General Lord Ramsbotham, wrote that New Labour had left the prison and probation service 'dysfunctional' and 'in crisis' (Leech 2010 p. ?). In his foreword to the annual Prisons Handbook Lord Ramsbotham accused Labour of 'government on the back of a fag packet' and said that 'the prisons are full of people who should not be in there for a variety of reasons' (Leech 2010 p. ?). He also said that the Labour administration had virtually destroyed the National Probation Service.

The Coalition's green paper on sentencing was published on 7 December 2010. Justice Secretary Kenneth Clarke said it represented a 'radically different approach' (Ministry of Justice 2010 e, p. ?). He set out three priorities - punishing offenders, protecting the public and reducing reoffending - and said the previous government's policy had fundamentally failed because of a lack of firm focus on reform and rehabilitation. 'The criminal justice system cannot remain an expensive way of giving the public a break from offenders, before 
they return to commit more crimes' (Ministry of Justice 2010e, p. 1). Clarke stated: 'Our plans represent a fundamental break with the failed and expensive policies of the past' (Ministry of Justice 2010e, p. ?).

A significant proportion of people who are sent to prison - some put the figure at over 85 per cent - are suffering from mental health problems. Some judges have said that the prison system is being used as a dustbin for people who needed treatment. The green paper outlined plans to work with the Department of Health to divert more offenders with mental illness and drug dependency into treatment marking another break with the Labour administration.

Underlining the differences in the field of home affairs between the Labour governments and the Coalition, in early January 2011 Nick Clegg said that the government intended to restore civil liberties in Britain with the same 'systematic ruthlessness' that the Labour government had taken them away. He highlighted the forthcoming reforms to Britain's libel laws which were intended to promote freedom of speech and a free press (Clegg 2011 ? and include in Bib).

\section{Political Tension and Controversy}

Several of the Coalition government's policies in the home affairs arena are controversial. As well as arguments with the Labour opposition there are also political disagreements within the Coalition itself. There have been some tensions between the Conservatives and the Liberal Democrats but there are also arguments within both parties themselves.

There is some disaffection within the Conservative Party, both within Parliament and without. A number of MPs have said that they feel that various promises in the 2010 Manifesto have been ignored in the Coalition programme. Complaints have surfaced that the party's principles and values have been compromised and that too much ground has been conceded to the Liberal Democrats. One backbench Conservative MP was quoted as saying 'There is a very strong sense that the tail is wagging the dog.'

One policy field where tension is especially evident is that of punishment and imprisonment. The Secretary of State for Justice, Kenneth Clarke, questioned whether 'prison works' - but Lord Howard, who coined this phrase when he succeeded Clarke as Home Secretary in 1993, 
has criticised the Coalition approach on several occasions and in late 2010 said that Clarke's approach was 'marred by a flawed ideology'. Howard's criticisms appeared to reflect the views of a section of Conservative thinking. Under the headline 'Prison Works', the Spectator made its opposition to Mr Clarke's approach clear and said that 'locking people up offers a very good return on the taxpayer's investment' (Spectator 2010).

In December 2010 the Home Secretary appeared to disagree with Kenneth Clarke when she appeared before the Home Affairs Select Committee and said 'prison works. But it must be made to work better' (May 2010 reference?). She explained that the rate of reoffending of exprisoners must be reduced. Some tabloid newspapers as well as backbenchers have expressed considerable concern at the new policy of reducing the prison population and developing other forms of punishment.

Another issue which has caused divisions is the proposal to allow people in prison to vote in elections. This change is needed to comply with a 2005 judgement by the European Court of Human Rights. It is a divisive issue as the Liberal Democrats support votes for prisoners but many Conservatives are opposed. The Coalition announced a compromise of giving the vote only to prisoners serving up to four years but Labour argued for just one year. In January 2011 a number of Tory rebels said they would oppose the proposal which seemed likely to come to a vote later in 2011.

Other contentious issues included the decision to close 93 magistrates' courts and 49 county courts and the cuts in the number of police officers. Arguments over a British bill of rights to replace the Human Rights Act were somewhat defused by referring the issue to an independent commission, but the disagreements may resurface in the future.

The reductions to legal aid may also lead to disputes between Conservatives and Liberal Democrats. In addition to the effects on vulnerable groups such as asylum seekers, the cuts seem likely to disadvantage women. The Ministry of Justice equality impact statement found that women would be disproportionately affected by the cuts in legal aid for family cases and divorce, immigration, employment, housing and welfare benefits.

Another area of potential disagreement between the Coalition partners is counter-terrorism. Both parties have been united in their criticism of the 'authoritarian' regime that New Labour 
established but arguments have persisted about the proper balance between civil liberties and counter-terrorism. The use of control orders was one issue on which there was division, and further disagreements may arise.

\section{Conclusion - Turning Old Thinking on its Head}

Introducing the Coalition programme, David Cameron and Nick Clegg stated that they believed in 'radical, reforming government, a stronger society, a smaller state, and power and responsibility in the hands of every citizen' (HM Government 2010b p. 8). This is a highly ambitious aspiration, especially in an age of austerity, and in the arena of home affairs the new government made a brisk and energetic start.

The new government's policies on home affairs contrast markedly with those of the preceding administration. The commitment of both partners to reverse Labour's 'erosion of civil liberties' was evident from the outset. This was given impetus by the requirement to save money, for example on identity cards. The huge cuts in public expenditure and the need for economies have also underpinned other Coalition policies, such as the decision to review legal aid and sentencing and to stop the costly ever-rising prison population.

Cameron and Clegg stated 'we are both committed to turning old thinking on its head and developing new approaches' (HM Government 2010b p.7). In terms of home affairs that is what seems to have happened. The policies of New Labour, and now their reversal by the Coalition, have turned old thinking on law and order 'on its head' and have forced a rethink of the conventional view of different political approaches in the law and order arena.

As shown in Figure 1, the conservative 'traditionalist' perspective is more authoritarian and tough-minded. It stresses punishment and retribution, deterrence, discipline and the removal of offenders from society. In office New Labour seems to have been increasingly drawn towards this right-wing (can we say 'conservative' instead?) approach to law and order and this was reflected in its policies and outcomes, such as the growing number of criminal offences, the curtailment of liberties and the ever-rising prison population. By contrast, the Coalition policies seem to fit more within the liberal 'progressive' perspective. This tends to place more emphasis on civil liberties and on rehabilitation, education and treatment for 
addictions and mental health problems. It stresses restorative justice and personal responsibility.

Figure 1: Different Approaches to Law and Order and Home Affairs

\begin{tabular}{|l|l|}
\hline \multicolumn{1}{|c|}{ Liberal 'Progressive' Perspective } & Conservative 'Traditionalist' Perspective \\
\hline Liberal and humanitarian & Authoritarian and disciplinarian \\
\hline Tender-minded & Tough-minded \\
\hline Rehabilitation and rewards & Punishment and retribution \\
\hline Remove social and economic causes & Deterrence through penalties \\
\hline Emphasis on civil liberties & Emphasis on police powers \\
\hline Stresses education and treatment & Stresses removal \\
\hline Stresses responsibility & Stresses discipline \\
\hline Rejects authoritarianism & Rejects 'permissiveness' \\
\hline Stresses 'social justice' & Stresses 'rule of law' \\
\hline
\end{tabular}

Many people and groups - perhaps a majority - accept views from both the perspectives shown in Figure 1. It might be said that these paradigms are over-simplifications of the real world of political argument (Benyon, 1994). Nonetheless, the two contrasting perspectives were evident in much of the political discussion about home affairs in 2010. For example, when the new Coalition abolished asbos the Labour frontbench spokesman Alan Johnson said this was 'yet another example of the government going soft on crime' (Johnson 2010? and include in Bib). Home Secretary Theresa May responded that sanctions 'should be rehabilitating and restorative rather than criminalising and coercive' (May 2010? and include in Bib).

On 30 June 2010 Jack Straw, who served as both Home Secretary and Justice Secretary in the Labour administration, used an article in the Daily Mail to attack the Coalition's policies on prisons and punishment. Mr Straw accused the Coalition of being soft 'hand-wringers' on 
crime and seemed to boast about the increase in the prison population under the Labour governments (Straw 2010? And include in Bib). It was an extraordinary indication of how far the Labour Party's policy reflected the traditional right-wing (again, can we say 'conservative'?) perspective on law and order, and the extent to which the Coalition government's approach represented a radical transformation.

Of course, as Harold Macmillan once noted, events can blow a government off course. Whether the Coalition is able to sustain its direction and momentum in home affairs will depend on factors such as public expenditure cuts, political leadership, and the quiescence or otherwise of opponents within the Coalition, especially within the Conservative Party. Above all it will depend on how successful the new policies are and whether terrorism, crime, antisocial behaviour or disorder decline - or increase, as many think they will. The Coalition has begun with a convention-challenging reforming approach but it may be difficult to maintain the course it has set. 


\section{References and Sources}

Benyon, J. (1994) Law and Order Review 1993, Leicester: CSPO.

Commission on English Prisons Today (2009) Do Better Do less - The Report of the Commission on English Prisons Today, London: the Howard League for Penal Reform.

Conservative Party (2010) Invitation to Join the Government of Britain, London:

Conservative Party.

Home Office (2010a) Draft Structural Reform Plan, London: Home Office.

Home Office (2010b) Policing in the $21^{\text {st }}$ Century: Reconnecting Police and the People. Cm 7925. Norwich: The Stationery Office.

Home Office (2010c) Business Plan 2011-15 Plan, London: Home Office.

HM Government (2010a) A Strong Britain in an Age of Uncertainty: The National Security Strategy, Cm 7953, Norwich: The Stationery Office.

HM Government (2010b) The Coalition Agreement, London: HMSO.

HM Prison Service (2010) Population Bulletin - Monthly November 2010, London: HM Prison Service.

HM Treasury (2010) Comprehensive Spending Review, London: HM Treasury.

Jenkins, S. (2010), Need Title?, The Guardian, 26 May.

Labour Party (2010) A Future Fair for All, London: Labour Party.

Leech, M. (2010) The Prisons Handbook 2010, Manchester: PRISONS.ORG.UK.

Liberal Democrats (2010) Liberal Democrat Manifesto 2010, London: Liberal Democrats.

Ministry of Justice (2010a) Draft Structural Reform Plan, London: Ministry of Justice.

Ministry of Justice (2010b) Business Plan 2011-15 Plan, London: Ministry of Justice.

Ministry of Justice (2010c) Proposals for the Reform of Civil Litigation Funding and Costs in England and Wales, Cm 7947, Norwich: The Stationery Office.

Ministry of Justice (2010d) Proposals for the Reform of Legal Aid in England and Wales, Cm 7967, Norwich: The Stationery Office.

Ministry of Justice (2010e) Breaking the Cycle: Effective Punishment, Rehabilitation and Sentencing of Offenders, Cm 7972, Norwich: The Stationery Office.

The Spectator (2010) Prison Works, 19 June. 
